\title{
The Double Jeopardy Clause as a Bar to Reintroducing Evidence
}

The double jeopardy clause of the Fifth Amendment forbids subjecting a defendant who has already been in jeopardy to retrial for the same offense. ${ }^{1}$ Although the clause was held applicable to the states a decade ago, ${ }^{2}$ its implementation varies widely across jurisdictions. The difficulty in formulating uniform standards stems from the breadth and conceptual complexity of double jeopardy problems. ${ }^{3}$ In order to focus on the problem of multiple litigation arising out of the same factual allegations, this Note examines double jeopardy in the posture of successive prosecutions ${ }^{4}$ for criminal offenses ${ }^{5}$ against the same defendant by the same sovereign. ${ }^{6}$ The discussion concentrates on successive prosecutions in which jeopardy has attached in the first trial, ${ }^{7}$

1. U.S. CoNsT. amend. V ("No person shall . . . be subject for the same offence to be twice put in jeopardy of life or limb. . . .") For a discussion of the common law roots of double jeopardy, see M. Friedland, Double Jeop.Ardy 5-15 (1969); J. Sigler, Double JEOPARDY 4-16 (1969).

2. Benton v. Maryland, 395 U.S. 784 (1969).

3. See United States v. Scott, 437 U.S. 82, 86-87 (1978) (overruling three-year-old precedent, United States v. Jenkins, 420 U.S. 358 (1975)); Crist v. Bretz, 437 U.S. 28, 32 \& n.6 (1978) (citing seven other cases from 1977 Term presenting "subtle and complex problems" of double jeopardy).

4. The Note considers only punishment imposed by sentence following conviction, thus obviating the need to determine what forms of sanctions are punishment for double jeopardy purposes. See, e.g., Standlee v. Rhay, 557 F.2d 1303 (9th Cir. 1977) (revocation of parole after acquittal on same charges in criminal trial not double jeopardy violation); United States v. Shapiro, 383 F.2d 680, 683 (7th Cir. 1967) (punishment by prison disciplinary board for act for which prisoner also convicted in criminal trial not double jeopardy violation).

5. Double jeopardy serves only to bar subsequent criminal prosecution for the same offense and thus permits adjudication of a civil suit based on an incident that was already prosecuted criminally. See, e.g., Helvering v. Mitchell, 303 U.S. 391 (1938); Le Tourneur v. Immigration \& Naturalization Serv., 538 F.2d 1368 (9th Cir. 1976), cert. denied, 429 U.S. 1044 (1977) (deportation after conviction not double jeopardy violation).

6. Conviction or acquittal in a federal or state court will not bar retrial for the same offense in the other system. Abbate v. United States, 359 U.S. 187 (1959); Bartkus v. Illinois, 359 U.S. 121 (1959). United States courts can also prosecute one who has already faced trial abroad. E.g., United States v. Martin, 574 F.2d 1359 (5th Cir.), cert. denied, 439 U.S. 967 (1978).

7. Jeopardy attaches before the verdict, see United States v. Perez, 22 U.S. (9 Wheat.) 579 (1824), at the point the jury was sworn, see Crist v. Bretz, 437 U.S. 28, 38 (1978); Downum v. United States, 372 U.S. 734 (1963). 
trial has proceeded to completion, ${ }^{8}$ and appeal has not upset the judgment. ${ }^{9}$

Under current law, a defendant, whether acquitted or convicted at a first trial, may be confronted with identical evidence at a second trial for an offense that could have been joined and tried in the initial prosecution. The clause bars such an action only if the offenses in each trial are the "same." Two centuries of interpretation, however, have provided no "same offense" standard capable of fulfilling the clause's intent. ${ }^{10}$ Moreover, a second legal doctrine, criminal collateral estoppel, also provides inadequate protection.

This Note seeks to correct the deficiencies of sole reliance on sameoffense tests and collateral estoppel to bar successive prosecutions. First, it examines the inadequacies of these two doctrines and establishes their failure to implement the goals for which the double jeopardy clause stands. Then the Note offers a proposal-a procedural mechanism liberalizing the application of collateral estoppel. This mechanism offers a means of improving double jeopardy protection without a radical reformation of current law.

\section{Same-Offense Tests: A Confusing Tangle}

A standard that determines what constitutes the same offense-the definition by which double jeopardy protection is accorded or withheld-is not easily developed. This problem lies at the heart of the double jeopardy guarantee and is its most vexing aspect. ${ }^{11}$ Existing tests have been unable to fulfill adequately the purposes of double jeopardy.

\section{A. The Purposes of Double Jeopardy}

Three principles underlie double jeopardy: it is wrong to retry an individual found not guilty; ${ }^{12}$ it is wrong to retry an individual already

8. The issue of the permissibility of retrial following mistrial comprises a large portion of double jeopardy law. See Schulhofer, Jeopardy and Mistrials, 125 U. PA. L. Rrv. 449 (1977). Current law permits a retrial if the declaration of mistrial or dismissal is supported by a high degree of necessity. Sce Arizona v. Washington, 434 U.S. 497 (1978); Lee v. United States, 432 U.S. 23 (1977).

9. If a defendant's appeal is successful, he may be retried only if the reversal is predicated on trial error. In such cases the retrial is conceptually a continuation of the original trial for the same offense. See Burks v. United States, 437 U.S. 1 (1978) (overruling three Supreme Court double jeopardy cases).

10. See pp. 965-69 infra (describing inadequacies of current same-offense tests); Ashe v. Swenson, 397 U.S. 436, 450-51 (1970) (Brennan, J., concurring) (meaning of "same offense" open to judicial construction since adoption of Fifth Amendment).

11. See J. SigleR, supra note 1, at 63-69; Haddad \& Mulock, Double Jeopardy Problems in the Definition of the Same Offense: State Discretion to Invoke the Criminal Process Twice, 22 U. FLA. L. REv. 515, 515 (1970). It is also the most frequently litigated double jeopardy issue. M. FriedLand, supra note 1 , at 89 .

12. Retrying the acquitted increases the likelihood of convicting the innocent. Swisher 
convicted; ${ }^{13}$ and it is wrong, if avoidable, to subject anyone to more than one trial. ${ }^{14}$ In addition to the increased threat of convicting the innocent or of violating the convicted's expectation of finality, the second trial itself is an overbearing use of governmental power. ${ }^{15}$ The clause attempts to free one who has already been placed in jeopardy from continuing anxiety, expense, and insecurity about his future. ${ }^{13}$ In order for this policy to be effectuated fully, it must extend not only to subsequent trials duplicating the same charge, but also to subsequent trials that involve the same factual allegations in a different charge that could have been consolidated in the first trial. ${ }^{17}$ The government, in needlessly retrying the same facts, prolongs the anxiety, expense, and in-

v. Brady, 438 U.S. 204, 216 (1978); Arizona v. Washington, 434 U.S. 497, 504 (1978). Innocent defendants may lack the stamina to fight the second time; they may also plead guilty initially rather than face protracted trials, realizing that even if the prosecutor once suffers defeat, he may be able to prevail in subsequent trials. Knowlton, Criminal Law and Procedure, 11 Rutgers L. REV. 71, 95 (1956). Subsequent trials permit the prosecutor to strengthen his case by coaching his witnesses to alter their testimony, see United States v. Scott, 437 U.S. 82, $105 \mathrm{n.4}$ (1978), by reexamining the weaknesses in his first presentation to strengthen the second, see United States v. Wilson, 420 U.S. 332, 352 (1975), or by preparing to counter the accused's defense, see M. Friedland, supra note I, at 4. Earlier prosecution can be treated by the prosecutor as a "dry run." See Ashe v. Swenson, 397 U.S. 436,447 (1970).

13. This principle is rooted as much in the need for finality as in solicitude for justice. North Carolina v. Pearce, 395 U.S. 711, 717-18 (1969); Ex parte Lange, 85 U.S. (18 Wall.) 163, 169 (1873). Once convicted, the defendant can plan his life only if his sentence is final. The double jeopardy clause thus seals off the first sentence from augmentation even when justice would not be offended by imposition of an additional sentence on one already convicted-as, for example, when facts come to light proving that the mitigating circumstances that moved the judge to clemency were manufactured. Diminution in sentence, however, is permitted. United States v. Benz, 282 U.S. 304 (1931).

14. Whether the first trial results in acquittal, conviction, or no verdict, a primary purpose of the double jeopardy clause is prevention of multiple trials. United States v. Ball, 163 U.S. 662, 669 (1896); see Price v. Georgia, 398 U.S. 323, 331 (1970) (regardless of ultimate legal consequence, second trial is itself "an ordeal not to be viewed lightly"); $c f$. United States v. Wilson, 420 U.S. 332, 336 (1975) (government permitted to appeal acquittal following guilty verdict, as reversal would mandate only reinstitution of verdict, not retrial).

15. The state, because of its vastly superior resources, must be denied power to subject defendants to the expense and ordeal of repeated trials for the same offense. United States v. Scott, 437 U.S. 82, 87, 95 (1978); id. at 105 (Brennan, J., dissenting). Thus, double jeopardy protects against use of judicial process as an instrument of oppression. Ashe $v$. Swenson, 397 U.S. 436, 459 (1970) (Brennan, J., concurring) ("Abuse of the criminal process is foremost among the feared evils that led to the inclusion of the Double Jeopardy Clause in the Bill of Rights."). Checking the virtually unfettered discretion that prosecutors in this country enjoy, see id. at 452; Jackson, The Federal Prosecutor, 31 J. AM. INST. Crim. L. \& Criminology 3 (1940), is the primary purpose of the clause, see J. Sigler, supra note 1, at 155. Effective rules to police prosecutors are required because they evince no reluctance to reprosecute for the same offense until satisfied with the sentence. Bray, Evidence of Prior Uncharged Offenses and the Growth of Constitutional Restrictions, 28 U. MIAMI L. REv. 489, 509 (1974).

16. Arizona v. Washington, 434 U.S. 497, 503-04 (1978); Green v. United States, 355 U.S. 184, 187 (1957). Moreover, the clause conserves societal resources and precludes inconsistent results due to multiple trials. M. FRIEDLAND, supra note 1 , at 4.

17. See, e.g., Gavieres v. United States, 220 U.S. 338 (1911). 
security suffered by the accused. Since there is no reason to assume that the prosecution could not have obtained the same result at one trial, and since the second trial entails harms against which the double jeopardy clause is aimed, the second trial violates double jeopardy purposes. ${ }^{18}$

\section{B. Same-Offense Tests}

Two alternative tests determine whether offenses are the same for double jeopardy purposes; both purport to implement the purposes of double jeopardy across all contexts. But, in many instances, neither prevents the government from reintroducing the same evidence at subsequent trials. Accordingly, both fail to prevent the harassment of multiple trials.

\section{The Same-Evidence Test}

Under the test most often used, two offenses are the same if each requires proof of the same facts. ${ }^{19}$ This same-evidence test, recognized by American courts for over a century, ${ }^{20}$ is based on the requirements of proof, not on the actual evidence tendered at trial. ${ }^{21}$ The Supreme Court articulated the test's current formulation in Blockburger $v$. United States: ${ }^{22}$ two offenses are distinct if each requires proof of a fact that the other does not. ${ }^{23}$

18. United States v. Mespoulede, 597 F.2d 329, 337 (2d Cir. 1979) (repeated risks of conviction and ordeal of multiple trials for same conduct violate core of double jeopardy clause).

19. See, e.g., King v. United States, 565 F.2d 356 (5th Cir. 1978) (following conviction for importing heroin, defendant convicted of conspiracy to import heroin); United States v. Hairrell, 521 F.2d 1264 (6th Cir. 1975) (following conviction for possessing counterfeit money, defendant can be prosecuted for same charge if different times and places involved).

20. The rule was first enunciated in England five years after the adoption of the Fifth Amendment, see Rex v. Vandercomb \& Abbott, 2 Leach 708, 720, 168 Eng. Rep. 455, 461 (Ex. 1796), but was not recognized in this country until eighty years later, see Morey v. Commonwealth, 108 Mass. 433, 434 (1871). Morey was soon followed by the Supreme Court. See Ex parte Nielsen, 131 U.S. 176 (1889).

21. See, e.g., Hattaway v. United States, 399 F.2d 431, 432 (5th Cir. 1968) (per curiam) ("Offenses are not the same if, upon the trial of one, proof of an additional fact is required which is not necessary to be proved in the trial of the other, although the same acts may be necessary to be proved in the trial of each.")

22. 284 U.S. 299, 304 (1932).

23. The Blockburger rule has been consistently reaffirmed. See, e.g., Brown v. Ohio, 432 U.S. 16l, 166 (1977). Under this rule, a greater and lesser included offense, e.g., aggravated and simple assaults, are classified as the "same," for only one requires allegation of an element not contained in the other. Id. at 168-69.

Commentators break the same-evidence test into separate branches: the same-requiredevidence, the same-alleged-evidence, and the same-actual-evidence. See, e.g., Note, Twice in Jeopardy, 75 YALE L.J. 262, 269-71 (1965) [hereinafter cited as Twice in Jeopardy]. 
In the context of a single trial on a multicount indictment, the same-evidence test fulfills the purposes of the double jeopardy clause. In such cases, the goals of protecting defendants against multiple litigation and preventing prosecutorial jury-shopping are irrelevant; only the goal of preventing multiple punishment for one offense is pertinent. The same-evidence test prevents multiple punishments by ensuring that the defendant not be convicted at one trial of more crimes than the jurisdiction has authorized.

But this test provides inadequate protection in cases of successive prosecutions. ${ }^{24}$ Its name notwithstanding, the same-evidence test does not bar a successive trial on the same evidence because the same evidence can support distinct charges for offenses requiring slightly different elements of proof. ${ }^{25}$ If criminal statutes have marginally different requirements for proof, this test eviscerates double jeopardy protection. ${ }^{26}$ It would not forbid such anomalies as six successive trials for

The first branch is the Blockburger test, the second refers to the requirements of proof as set forth in the indictment, and the third bars retrial if the same evidence is introduced at both trials. Although a few older cases followed the same-alleged-evidence test, see, e.g., People v. Brannon, 70 Cal. App. 225, 232, 233 P. 88, 91 (1924); State v. Nash, 86 N.C. $650,651-52$ (1882), it has fallen in the last half-century into deserved desuetude, see Note, Successive Prosecutions Based on the Same Evidence as Double Jeopardy, 40 YALE L.J. 462, 463 (1931). It is doubtful whether the same-actual-evidence test has ever been followed. Two cases are usually cited as supporting this test: People v. Martinis, 46 Misc. 2d 1066, 261 N.Y.S.2d 642 (Sup. Ct. 1965), and Estep v. State, 11 Okla. Crim. 103, 143 P. 64 (1914). See Twice in Jeopardy, supra, at 270 n.33. The first case, however, is a disguised ruling of collateral estoppel; the second case, one of double jeopardy's most confused expositions, mentions the test only in dictum.

Courts today uniformly apply the Blockburger formulation, although they sometimes use terminology that perpetuates the illusion that other tests retain their vitality. See, e.g., Robbins v. United States, 476 F.2d 26, 32 (10th Cir. 1973) (identity of charges hinges on "facts alleged" in two indictments).

24. Commentators distinguish simultaneous from successive prosecutions, and some advocate differential treatment for double jeopardy in the two contexts. E.g., Note, Statutory Implementation of Double Jeopardy Clauses: New Life for a Moribund Constitutional Guarantee, 65 YALE L.J. 339, 359-68 (1956). Others contend that double jeopardy is completely inapplicable to simultaneous prosecutions. E.g., Fisher, Double Jeopardy: Six Common Boners Summarized, 15 U.C.L.A. L. REv. 81, 86 (1967). Courts, by contrast, are insensitive to the distinction. See, e.g., Brown v. Ohio, 432 U.S. 161, 166 (1977) (applying Blockburger rule, derived from simultaneous prosecutions, to successive-trial context).

25. Iannelli v. United States, 420 U.S. 770, 785 n.17 (1975); see Gavieres v. United States, 220 U.S. 338 (1911) (defendant previously convicted for behaving in indecent manner in public place; subsequently convicted on same evidence for insulting public officer).

26. See, e.g., United States v. Grant, 549 F.2d 942 (4th Cir.), cert. denied, 432 U.S. 908 (1977) (armed robbery separate statutory crime from carrying and using firearms in commission of felony). The twentieth century proliferation of statutory definitions of different crimes is a well-recognized phenomenon. See Ashe v. Swenson, 397 U.S. 436, 445 n.10 (1970); Note, Double Jeopardy and the Multiple-Count Indictment, 57 YaLe L.J. 132, 133 (1947). 
one act of sexual intercourse, ${ }^{27}$ seventy-five successive trials for as many poker hands, ${ }^{28}$ and five successive trials for the simultaneous embezzlement of five $\$ 100$ bonds. ${ }^{29}$ Not even successive acquittals would free the defendant from the scourge of retrial or of reintroduction of the same evidence to prove the defendant committed a "similar act" to the one on trial. ${ }^{30}$

In virtually all cases, offenses that arise from the same evidence can be prosecuted together. When, instead of joining all such offenses in a single trial, the government chooses to present essentially equivalent evidence to successive juries, it may be seeking to maximize the prospects of at least one conviction or to guarantee adequate punishment. Thus the same-evidence test enables the prosecution to circumvent the double jeopardy clause. ${ }^{31}$

\section{The Same-Transaction Test}

The same-transaction test requires that "all the charges against a defendant that grow out of a single criminal act, occurrence, episode, or transaction" be prosecuted together at one trial. ${ }^{32}$ Historically, the

27. See Commonwealth v. Burk, 2 Pa. County Ct. 12 (1886) (conviction for adultery, fornication, and bastardy); Note, Double Jeopardy and the Concept of Identity of Offenses, 7 BrookLYN L. REv. 79, 82 (1937) (possibility also of convictions for rape, incest, and impairing morals of minor).

28. See Johnson v. Commonwealth, $201 \mathrm{Ky} .314,256$ S.W. 388 (1923) (each act of betting distinct offense).

29. See Commonwealth v. Butterick, 100 Mass. 1, 8-9 (1868) (each serial number acts as separate proof for different offense).

30. See, e.g., Jones v. Blankenship, 602 F.2d 650 (4th Cir. 1979) (defendant acquitted of murder because jury found malice lacking; subsequently convicted for malicious wounding of another victim of same shotgun blast); United States v. Cylkouski, 556 F.2d 799 (6th Cir. 1977) (following acquittal of conspiracy to violate federal gambling laws, defendant prosecuted for federal offense of conspiracy to violate state gambling laws).

The prosecution also frequently introduces identical evidence of similar acts. Such "similar-acts evidence" shows that the defendant previously committed acts resembling the current charge. It can be introduced to show motive, intent, modus operandi, and various other elements, but not to show recidivism or evil character. See FED. R. Evid. 404(b). Similar-acts evidence is currently admissible even when it underlies a previous acquittal. See, e.g., Crisafi v. Oliver, 396 F.2d 293 (9th Cir.), cert. denied, 393 U.S. 889 (1968) (constitutional to admit testimony of prosecutrix from previous rape case in which defendant acquitted, to show characteristic behavior pattern). But see Wingate $v$. Wainwright, 464 F.2d 209 (5th Cir. 1972) (when defendant acquitted of two previous robberies, evidence that he committed them in trial for third robbery inadmissible because of double jeopardy).

31. Justice Brennan criticizes the same-evidence test not merely for failing to enforce the constitutional guarantee against double jeopardy, but for effectively annulling it. See Ashe v. Swenson, 397 U.S. 436, 451 (1970) (Brennan, J., concurring).

32. Brown v. Ohio, 432 U.S. I61, I70 (1977) (Brennan, J., concurring). Under this test, incidents of the same transaction, whether repeated commissions of the same crime, such as numerous poker hands at one sitting, or temporally proximate or simultaneous commissions of separate crimes, such as incest and rape or burglary and larceny, must be tried together. 
common law required such compulsory joinder. ${ }^{33}$ Because this joinder is inapplicable to simultaneous charges, it reflects a sensitivity to the distinction between simultaneous and successive prosecutions left unaddressed by the same-evidence test. Moreover, the same-transaction test serves the goals of economy and convenience. In contrast to the same-evidence test, which allows precisely the same evidence to be reintroduced at successive trials, the same-transaction test forbids repetitive litigation over the same factual contentions..$^{34}$

Although ihe same-transaction test is theoretically compelling, in practice it offers inadequate protection because it is impossible to define its content precisely. "Transaction" is a malleable term; no definition can forestall prosecutorial strategies to try separately incidents of the same course of conduct. Only the breadth of one's perspective and imagination sets the bounds on the "same transaction." 35

The test's inadequacies are apparent in the states that follow it; ${ }^{38}$ it can be manipulated to obtain opposite results. ${ }^{37}$ Thus some defendants enjoy legitimate double jeopardy protection, while others in virtually

33. From the Middle Ages through the eighteenth century, the defendant was tried for the entire underlying factual transaction, not for a statutorily defined offense with particular evidentiary requirements. See Note, supra note 24 , at $342-43$; cf. Raven's case, 84 Eng. Rep. 1065, 1073 (1662) (applying Statute of Clergy, $25 \mathrm{Ed}$. 3, stat. 6, c.5, enacted in 1350, which required use of same-transaction test in case against clergyman).

34. Compulsory joinder in civil trials is urged to conserve judicial resources, to prevent inconsistent results, and to protect the defendant against vexatious litigation. See F. James \& G. Hazard, Civil Procedure 542-43 (2d ed. 1977). In criminal cases, the judicialresources problem is no less acute, inconsistent results are even more egregious, and harassment of the defendant is more severe and less rectifiable. The civil defendant does not live in fear of his liberty and can recover costs if the plaintiff's suit proves groundless. The criminal defendant enjoys no such protection. $C f$. United States v. Oppenheimer, 242 U.S. 85, 87 (1916) ("It cannot be that the safeguards of the person, so often and so rightly mentioned with solemn reverence, are less than those that protect from a liability in debt.").

35. State v. Boyd, 533 P.2d 795, 797 (Or. 1975); Harris v. State, 193 Ga. 109, 116-17, 17 S.E.2d 573, 57c-79 (1941).

36. Although several states have adopted the same-transaction test, see, e.g., Com. monwealth v. Campana, $452 \mathrm{~Pa} .233,304$ A.2d 432, vacated, 414 U.S. 808 (1973), adhered to on remand, 455 Pa. 622, 314 A.2d 854, cert. denied, 417 U.S. 969 (1974); Kellett v. Superior Court, 63 Cal. 2d 822, 409 P.2d 206, 48 Cal. Rptr. 366 (1966), it has never been adopted in the federal courts. See, e.g., United States v. Snell, 592 F.2d 1083 (9th Cir.), cert. denied, 442 U.S. 944 (1979); Vanetzian v. Hall, 562 F.2d 88 (1st Cir. 1977); United States v. Hinton, 543 F.2d 1002 (2d Cir.), cert. denied, 429 U.S. 980 (1976). It has, however, been ceaselessly championed in dissents by Justice Brennan. See, e.g., Thompson v. Oklahoma, 429 U.S. 1053, 1054 (1977) (Brennan, J., dissenting) (citing ten dissents advocating sametransaction test).

The same-transaction test also enjoys wide support among comnentators. E.g., Note, Double Jeopardy: A Protection or an Empty Promise? 25 U. FLA. L. REV. 838, 842 (1973); Twice in Jeopardy, supra note 23 , at 292-96.

37. Compare State v. Gregory, 66 N.J. 510, 333 A.2d 257 (1975) (conviction for selling heroin bars subsequent prosecution for possession) with State v. Vasquez, 135 N.J. Super. 303, 343 A.2d 152 (1975) (permitting separate prosecutions for selling cocaine and possessing it on day search warrant grounded in first offense executed). 


\section{identical circumstances are either deprived of their constitutional right $^{38}$ or given an unjust immunity ${ }^{30}$ The problem is inherent in reliance on the definition of so protean a term. ${ }^{40}$ Because the test is toothless, it fails either to offer systematic protection to defendants ${ }^{41}$ or to remedy the defects of the same-evidence test. ${ }^{42}$}

38. Compare People v. White, 390 Mich. 245, 212 N.W.2d 222 (1973) (fact that prior kidnapping conviction was for acts committed in different county does not allow subsequent prosecution for rape and assault during same transaction) with People v. Ward, 30 Cal. App. 3d I30, 103 Cal. Rptr. 67 (1973) (fact that prior kidnapping, assault, and rape of victim was committed in different county permits subsequent prosecution for sex perversion upon victim's mother, performed in same car shortly afterwards). Differentiating between the transaction and the larger criminal enterprise is but another way of carving a transaction into separate offenses, the vice this test was meant to eradicate. See People v. Jackson, 391 Mich. 323, 342, 217 N.W.2d 22, 29 (1974) ("[a]lthough the attempted unlawful possession of a credit card charge grew out of the assault with intent to rob charge," two were "separate transactions"); Note, One Transaction-One Conviction: The Texas Doctrine of Carving, 25 Baylor L. REv. 623, 630-31 (1973) (Texas same-transaction variant applied in virtually every conceivable way).

39. Unjust immunity arises in states that have adopted the identical-element test, a variant of the standard same-transaction test. This variant finds offenses to be the same if they share a common essential element. Thus, rape and kidnapping could be prosecuted separately because they share no identical element. See, e.g., State v. Jacobs, 93 Ariz. 336, 380 P.2d 998, appeal dismissed, 375 U.S. 46 (1963). But because the essential element of a gun is common to assault with a deadly weapon and attempted kidnapping while armed with a gun, conviction for both is impermissible. See, e.g., State v. Mitchell, 106 Ariz. 492, 478 P.2d 517 (1970).

The identical-element test is too restrictive. The legislature may justly wish to punish two crimes arising from the same incident. See note 27 supra. Under the identical-element test, separate convictions for the two crimes, whether at the same or successive trials, are barred; accordingly, legislative will is contravened. Such a contravention in the context of simultaneous prosecutions cannot be justified. Eliminating the possibility of multiple convictions does not fulfill the goals of the double jeopardy clause. $C f$. Gore v. United States, 357 U.S. 386 (1958) (three convictions at one trial permissible if Congress intended to proscribe same activity under three statutes). Moreover, even if the test were limited to successive prosecutions, it would provide no protection against prosecuting successive commissions of the same crime at separate trials.

40. It has been claimed that recurrent factual patterns will emerge by which the meaning of "same transaction" will become fixed. See Twice in Jeopardy, supra note 23, at 298 n.158. The experience both of those states that have adopted the test, see note 38 supra, and of civil law belies that claim. See IB Moore's Federal Practice of 0.410[1], at 115758 (2d ed. 1974); Cleary, Res Judicata Reexamined, 57 Yale L.J. 339 (1948).

Even Justice Brennan concedes that the same-transaction test is not self-defining. Ashe v. Swenson, 397 U.S. 436, 454 n.8 (1970) (Brennan, J., concurring). This want of definitional precision is most keenly apparent in the totality-of-the-circumstances variant of the same-transaction test. That variant considers all that transpired to determine whether two offenses are the same. E.g., State v. Stiefel, 256 So. 2d 581, 583-84 (Fla. Dist. Ct. App. 1972). Such a formless test depends entirely upon the judge's predilections. It implements haphazardly at best the invariable principle of finality which lies at the heart of the double jeopardy protection.

41. See State v. Fitzgerald, 267 Or. 266, 273, 516 P.2d 1280, 1284 (1973) (applying de facto identical-element test to effectuate same-transaction test); State v. Patterson, 513 P.2d 517 (Or. App. 1973) (applying de facto same-evidence test to effectuate same-transaction test).

42. Compare Hoag v. New Jersey, 356 U.S. 464 (1958) (under same-evidence test, there are as many crimes as victims of robbery) with State v. Gilbert, 574 P.2d 313, 318 (Or. 1978) (under same-transaction test, there are as many crimes as owners whose stolen property is held in defendant's residence). 


\section{Criminal Collateral Estoppel-An Inadequate Supplement}

Because the same-offense tests, which have been developed to give content to the Fifth Amendment, fail to implement the purposes of double jeopardy, many defendants are retried illegitimately and society is needlessly deprived of the right to try others for the first time. The same-offense tests, however, do not exhaust the defendant's double jeopardy protection. Criminal collateral estoppel and res judicata are also part of the clause's protection and may afford relief when the strictures of the same-offense tests are not met. ${ }^{43}$

\section{A. Collateral Estoppel and Res Judicata}

Neither res judicata nor collateral estoppel adequately supplements the protection afforded by the same-offense tests; res judicata is rarely applicable to situations in which the same-offense tests do not already provide adequate shelter, while collateral estoppel seldom provides any protection. Res judicata requires that a final judgment on the merits foreclose any further litigation of the same claim between the same parties. ${ }^{44}$ Collateral estoppel applies against parties who have had a full and fair opportunity to litigate an issue $e^{4 \overline{5}}$ and precludes relitigating facts determined in that prior adjudication. ${ }^{46}$ The doctrine prevents

43. Both res judicata and collateral estoppel preserve the finality of judgments. Crist v. Bretz, 437 U.S. 28, 33 (1978). Each is based on considerations of economy and the desire for certainty in legal relations. See Hoag v. New Jersey, 356 U.S. 464,470 (1958) (purpose of collateral estoppel "to eliminate the expense, vexation, waste, and possible inconsistent results of duplicatory litigation"); Commissioner v. Sunnen, 333 U.S. 591, 597 (1948) (res judicata "rests upon considerations of economy of judicial time and public policy favoring the establishment of certainty in legal relations").

44. See Lawlor v. National Screen Serv. Corp., 349 U.S. 322, 326 (1955); 1B Moore's Federal Practice o 0.405[1], at 621-22 (2d ed. 1974). Judgment for the defendant bars the plaintiff from reinstituting his suit, while judgment for the plaintiff merges all grounds of recovery and precludes further proceedings.

45. Formerly, collateral estoppel applied only between parties and those in privity with them. Bigelow v. Old Dominion Copper Mining \& Smelting Co., 225 U.S. 111, 127 (1912). Today, while parties and their privies are still bound by adverse judgments, nonparties may also claim the benefit of favorable judgments. See, e.g., Parklane Hosiery Co. v. Shore, 439 U.S. 322 (1979); Blonder-Tongue Laboratories, Inc. v. University of Ill. Foundation, 402 U.S. 313 (1971) (patentee bound by prior determination of patent invalidity in subsequent suit against different defendant); Gambocz v. Yelencsics, 468 F.2d 837 (3d Cir. 1972) (res judicata applied for benefit of new defendants).

46. Cromwell v. County of Sac, 94 U.S. 351, 353 (1876); 1B Moore's Federal Practice I $0.405[1]$, at $622-23$ (2d ed. 1974). Collateral estoppel differs from res judicata in that it does not foreclose initiating a new trial, but only relitigating particular facts at a new trial. In addition, it applies only to facts actually determined at the first trial, not to those that could have been litigated but were not. Res judicata, by contrast, terminates even those grounds of recovery or defenses that could have been, but in fact were not, presented. See, e.g., NLRB v. International Bhd. of Teamsters, 428 F.2d 994, 999 (2d Cir. 1970). 
a party from contesting in subsequent litigation a fact determined adversely to him.

Although the doctrines of collateral estoppel and res judicata apply primarily to civil litigation, each also operates in the criminal realm. ${ }^{47}$ Yet neither reliably fulfills the goals of double jeopardy. Criminal res judicata largely overlaps double jeopardy protection; both bar relitigation of an acquittal and merge further punishment arising from the same offense into an initial conviction. Res judicata and double jeopardy diverge, however, in several important respects. Double jeopardy bars retrial in a large number of cases in which res judicata is inapplicable because final judgment has not been reached, ${ }^{48}$ and res judicata on rare occasions disposes of a case with finality on procedural grounds without the attachment of jeopardy. ${ }^{49}$ But even in those cases, res judicata bars retrial only for the identical offense for which the defendant has been previously tried. ${ }^{50}$ It does not foreclose presentation of the same evidence to prove a different statutorily-defined offense. Accordingly, it cannot serve as the vehicle to expand double jeopardy protection. This discussion therefore focuses on criminal collateral estoppel, which results in the preclusion of particular factual issues, rather than on res judicata, which causes the preclusion of a whole criminal charge. ${ }^{51}$

\section{B. Inadequacies of Criminal Collateral Estoppel}

In the 1970 Supreme Court case of Ashe v. Swenson, ${ }^{52}$ the defendant had been tried previously for robbing one of six victims of a mass hold-up and a Missouri jury had found him not guilty. Missouri subsequently charged Ashe with a second robbery count and a different

47. See IB Moore's Federal Practice q 0.418[2], at 2751 (2d ed. 1974). Res judicata was first applied in a criminal case. See Rex v. Duchess of Kingston, 20 How. St. Tr. 355, 538 (1776).

48. For instance, if a person were prosecuted for robbery and the prosecution dismissed the case in mid-trial, double jeopardy would bar reprosecution for robbery. See note 7 supra (jeopardy attaches when jury sworn). Res judicata, however, would allow the robbery retrial. See, e.g., FTC v. Food Town Stores, Inc., 547 F.2d 247 (4th Cir. 1977) (per curiam) (no res judicata before final judgment).

49. E.g., United States v. Oppenheimer, 242 U.S. 85 (1916) (res judicata bars government from pressing same charge when, under erroneous interpretation of statute of limitations, judgment for defendant was entered prior to attachment of jeopardy).

50. The same-offense test used for res judicata determinations is literal identity; for example aggravated assault is the "same" only as aggravated assault, not simple assault.

51. Nomenclature in this field is confusing, as the term res judicata has a generic meaning comprising both collateral estoppel and the more limited usage of res judicata. Courts therefore frequently refer to collateral estoppel as res judicata. 1B MoorE's Federal Practice đf 0.405[1], at 621 (2d ed. 1974).

52. 397 U.S. 436 (1970). 
jury found him guilty. The Supreme Court reversed Ashe's conviction, holding that the double jeopardy clause includes collateral estoppel protection. ${ }^{53}$ Collateral estoppel forecloses litigation of an issue when it appears that a rational jury could have based its verdict on no other issue; a high probability that the jury so concluded will not suffice. ${ }^{54}$

In a civil jury trial, parties who wish to foreclose future inquiry into adjudicated facts may request specific findings of fact from the jury. ${ }^{.55}$ In bench trials, the judge may pronounce certain facts or list them in an opinion. ${ }^{56}$ In either case, the factual grounds for decision are explicit. The criminal jury, by contrast, returns only a general verdict-guilty or not guilty. 57 Thus, while the civil special verdict

53. Id. at 445. Virtually identical facts had passed the Court's scrutiny under the due process clause in Hoag v. New Jersey, 356 U.S. 464 (1958), before the double jeopardy clause was incorporated into the Fourteenth Amendment by Benton v. Maryland, 395 U.S. 784 (1969). Ashe left Hoag standing but emasculated.

Although admittedly never before recognized as a constitutional requirement, collateral estoppel was traced by the Court in Ashe as "an established rule of federal criminal law" to United States v. Oppenheimer, 242 U.S. 85 (1916). 897 U.S. at 443 . But Oppenheimer addressed res judicata, not collateral estoppel. 242 U.S. at 87 (bar theory of res judicata followed; no collateral estoppel analysis); see p. 970 supra (distinguishing two doctrines). The misperception that oppenheimer dealt with collateral estoppel has become engrained. See, e.g., Hoag v. New Jersey, 356 U.S. 464, 471 (1958); Note, Constitutional Collateral Estoppel: A Bar to Relitigation of Federal Habeas Decisions, 80 YALE L.J. 1229, 1246 (1971). Whether resulting from misperception or intention, the Ashe Court's reliance on Oppenheimer comprehends both criminal collateral estoppel and criminal res judicata. Hence, while in the civil sphere collateral estoppel and res judicata are both known generically as res judicata, see note $\mathbf{5 1}$ supra, both are generically labeled collateral estoppel in criminal law.

The doctrine of collateral estoppel, though recently elevated to constitutional stature, is not new. Hoag v. New Jersey, 356 U.S. 464, 470-71 (1958) (collateral estoppel "has been widely employed in criminal cases in both state and federal courts"). Ashe has not changed the application of federal collateral estoppel, see 397 U.S. at 444 , and post-Ashe courts apply criminal collateral estoppel no differently from their predecessors. Compare United States v. Cioffi, 487 F.2d 492, $498-99$ (2d Cir. 1973), cert. denied, 416 U.S. 995 (1974) with United States v. Kramer, 289 F.2d 909, 916 (2d Cir. 1961).

54. Ashe v. Swenson, 397 U.S. 436, $443-44$ (1970); United States v. Mespoulede, 597 F.2d 329, 333 (2d Cir. 1979) ("[T] he defendant must carry the burden of proving that the fact-finder acquitted him because it resolved in his favor the very issue that he seeks to foreclose from consideration in the second trial.")

Although resolution in the defendant's favor means only that the fact-finder entertained a reasonable doubt on the factual issue, the issue is excluded even when offered by the prosecution as probative evidence that need not be proven beyond a reasonable doubt. Id. at 334; United States v. Kramer, 289 F.2d 909, 915-16 (2d Cir. 1961). The probability, however, need not rise to logical certainty. The Ashe Court specifically announced that it was not following "the hypertechnical and archaic approach of a 19th century pleading book," but was proceeding "with realism and rationality." 397 U.S. at 444. It noted that any more rigid approach would amount to a rejection of collateral estoppel. $I d$.

55. Such findings may be a special verdict, FED. R. Crv. P. 49(a), or answers to interrogatories, FED. R. Crv. P. 49 (b).

56. F. JAMES \& G. HAZARd, supra note 34 , at 567.

57. Special verdicts are rarely used in criminal cases, eren in those jurisdictions that permit them. See Note, The Double Jeopardy Clause: Refining the Constitutional Proscription Against Successive Criminal Prosecutions, 19 U.C.L.A. L. REv. 804, 828-29 (1972). 
frequently determines facts for future litigation, the criminal general verdict rarely does so..$^{\text {s }}$

An acquittal generally provides no basis for the defendant to invoke collateral estoppel because it at most means that one fact needed for conviction is lacking. Since an acquittal is couched in a general denial of guilt, the identity of that essential fact, as well as of those facts that the jury may have found against the defendant, is hidden. Particularly when alternative defenses are used, the difficulties of determining the jury's mental processes are insuperable. ${ }^{59} \mathrm{~A}$ case like Ashe in which a court can trace the jury's deliberations in reaching an acquittal with reasonable certainty is therefore rare. ${ }^{60} \mathrm{~A}$ conviction, by contrast, conclusively determines all issues adversely to the defendant and thus could support collateral estoppel. But the Sixth Amendment prohibits this use of a conviction in subsequent criminal trials. ${ }^{61}$ The irony is that while criminal collateral estoppel is rooted in the barren clay of acquittals, it is fenced off from the fertile soil of convictions. The problem results from the wholesale importation of collateral estoppel, a doctrine geared to the special verdict of civil law, into criminal law, a realm committed to the general verdict.

58. United States v. Mespoulede, 597 F.2d 329, 333 (2d Cir. 1979). Exceptions occur when the trial judge directs a verdict for the defendant because the prosecution has failed to prove a specific fact, when the defendant concedes all but one issue, or when he admits everything but relies on an affirmative defense such as insanity.

59. Under the current rule, defense counsel may seek to preserve collateral estoppel in future cases only at the price of turning the instant trial into a one-issue contest, foregoing alternative defenses, not challenging general credibility, not blanketly denying the government's case or pointing to its weak links. See Commonwealth v. Campana, $452 \mathrm{~Pa}$. 233, 247, 304 A.2d 432, 438, vacated, 414 U.S. 808 (1973), adhered to on remand, $455 \mathrm{~Pa}$. 622, 314 A.2d 854, cert. denied, 417 U.S. 969 (1974).

60. See United States v. King, 563 F.2d 559, 561 (2d Cir. 1977), cert. denied, 435 U.S. 918 (1978); United States v. Gugliaro, 501 F.2d 68, 70 (2d Cir. 1974). Unlike the result in Ashe, typically no collateral estoppel arises upon acquittal. See, e.g., Moton v. Swenson, 488 F.2d 1060 (8th Cir. 1973), cert. denied, 417 U.S. 957 (1974) (post-Ashe decision upholding successive Missouri prosecutions for robbery of separate victims of same transaction); LaFond v. Quatsoe, 325 F. Supp. 1010, 1014 (E.D. Wis. 1971) (previous trial's finding that proof insufficient to establish intercourse with child insufficient for collateral estoppel on contribution to delinquency of a minor). But see Bigelow, Former Conviction and Former Acquittal, 11 Rutgers L. REv. 487, 500 (1957) (asserting that in nine out of ten criminal cases, only one issue is contested).

The rule that an acquittal determines all issues in favor of the defendant has been explicitly followed in several cases. E.g., United States v. Clavin, 272 F. 985 (E.D.N.Y. 1921); United States v. Rachmil, 270 F. 869 (S.D.N.Y. 1921), cert. denied, 262 U.S. 751 (1923); People v. Walker, 25 Misc. 2d 942, 944, 212 N.Y.S.2d 936, 938 (1960); State v. Little, 87 Ariz. 295, 305, 350 P.2d 756, 762-63 (1960). But see United States v. Halbrook, 36 F. Supp. 345, 348, 350 (E.D. Mo. 1941) (criticizing Clavin and Rachmil); Developments in the Law-Criminal Conspiracy, 72 HARv. L. Rev. 920,972 n.378 (1959) (criticizing Clavin).

61. The Sixth Amendment entitles a criminal defendant to "a trial de novo of the facts alleged and offered in support of each offense charged against him and to a jury's independent finding with respect thereto." United States v. DeAngelo, I38 F.2d 466, 468 (3d Cir. 1943). 
Suggestions to obviate the inscrutability of general verdicts have been made. Special verdicts could be instituted in criminal cases. This, however, would undermine a basic rationale for the jury-tempering the occasional harshness of the law with community feelings. ${ }^{62}$ Interviewing jurors from the first trial to determine the basis for their verdict would also violate the fundamental precept of jury autonomy ${ }^{63}$

Thus many acquitted defendants are denied collateral estoppel on issues the jury actually found in their favor because it is impossible to prove jury findings with certainty. ${ }^{64}$ Collateral estoppel accordingly does not adequately supplement the same-offense tests. It too permits introduction of the same evidence at a subsequent trial in the only context in which it arises-following an acquittal.

\section{A Hypothetical Case}

An example best illustrates the inadequacies of current law. Let us assume that a defendant is charged with assault with a deadly weapon based on the alleged fact that he drew a gun and pointed it at a policeman. He offers two alternative defenses: he was unarmed and he was acting in self-defense against unlawful force. ${ }^{65} \mathrm{~A}$ jury finds him not guilty. The state subsequently tries the defendant for possession of a deadly weapon by an ex-felon ${ }^{66}$ based on the same putative assault. This time the defendant is convicted, but the judge exacts only a sus-

62. The jury must be left free to render the simple justice of acquittal, instead of being channeled down a path, each incremental step along which is inexorable, whose ultimate destination is conviction. See United States v. Spock, 416 F.2d 165, 181 (Ist Cir. 1969). Nor does the solution lie in allowing the defendant to request a special verdict, as suggested in Gershenson, Res Judicata in Successive Criminal Prosecutions: Hoag v. State of New Jersey and a Proposal, 25 Brooklyn L. Rev. 33, 36-38 (1958). This would pressure him to waive his Sixth Amendment right to an unfettered jury decision, thereby usually increasing the chances of his conviction, in order to secure the benefits of collateral estoppel in subsequent trials should he be acquitted. Confronting the defendant with such a Hobson's choice cannot be permitted. Cf. Simmons v. United States, 390 U.S. 377, 389-94 (1968) (defendant could not be required to surrender Fifth Amendment privilege against compulsory self-incrimination in order to assert Fourth Amendment claim).

63. Stein v. New York, 346 U.S. 156, 178 (1953); cf. McDonald v. Pless, 238 U.S. 264, 267-68 (1915) (allowing such practice in civil cases would "make what was intended to be a private deliberation, the constant subject of public investigation-to the destruction of all frankness and freedom of discussion and conference").

64. See, e.g., United States v. Dockery, 49 F. Supp. 907, 908 (E.D.N.Y. 1943) (previous acquittal of possessing alcohol held not to bar prosecution for sale of same; "[w]hile improbable ... one may sell distilled spirits without possessing it"); United States v. Halbrook, 36 F. Supp. 345, 348-49 (E.D. Mo. 1941) (prosecution for overt acts permitted although jury in former case may have been of opinion, in reaching verdict of not guilty, that defendants had not committed offenses charged in present indictment).

65. The latter defense has been accepted in a similar context. See People v. Cherry, 307 N.Y. 308, 121 N.E.2d 238 (1954).

66. See, e.g., Cox v. Gaffney, 459 F.2d 50 (10th Cir.), cert. denied, 409 U.S. 863 (1972). 
pended sentence. The prosecutor, seeking a harsher sentence, obtains yet another indictment on the same facts, ${ }^{67}$ this time for assault upon a police officer.

Despite its unfairness to the defendant, this series of prosecutions is sanctioned by current law. The three offenses are separate under the dominant same-evidence test ${ }^{68}$ because each requires proof of an element not contained in the others; ${ }^{60}$ thus separate prosecutions will lie. Collateral estoppel provides no additional protection. The basis of the first jury's acquittal is uncertain, because it is unclear whether the jurors believed the defendant was unarmed or justified in his assault. The acquittal therefore does not bar the second prosecution. Because the defendant was convicted at the second trial, the conviction cannot be invoked to support collateral estoppel. ${ }^{70}$ There is therefore no bar to the third prosecution.

This hypothetical exposes telling inadequacies in the current law. First, the jury in the first trial acquitted the defendant because it thought he was either unarmed or acting justifiably. The second prosecution challenges the former possibility while the third flouts the latter. Because it cannot be ascertained which prosecution violates the defendant's rights, current law allows both. Second, if the first two charges had been tried together with the same results, there would have been conclusive proof that the jury determined the defendant was armed but acting justifiably. This finding would have collaterally estopped the third prosecution. But because in the actual sequence the defendant was forced to endure two trials over the same evidence, he is afforded no protection against a third. Finally, the two juries that reviewed the identical evidence reached contrary conclusions. Yet criminal collateral estoppel is based on the premise that a review of

67. See, e.g., Brief for Petitioner, App. E, p. 51, Ciucci v. Illinois, 356 U.S. 571 (1958) (prosecutor brought successive murder charges until death penalty imposed); People v. White, 390 Mich. 245,259 n.9, 212 N.W.2d 222, 228 n.9 (1973) (prosecutor admits that one reason for bringing rape charge was dissatisfaction with sentence imposed for kidnapping conviction).

68. Although two courts found variants of this hypothetical fact situation to be parts of the same transaction, see Kellett v. Superior Court, 63 Cal. 2d 822, 409 P.2d 206, 48 Cal. Rptr. 366 (1966); State v. Ahuna, 52 Hawaii 321, 474 P.2d 704 (1970), virtually any result can be reached under that test, see note 38 supra; cf. Fervs v. State, 1 Ga. App. 122, 125, 58 S.E. 64, 66 (1907) (finding defendant's two consecutive shootings in one melee two transactions). Nor can the identical-element test provide adequate protection; it would not prevent successive trials on the second and third charges. See note 39 supra.

69. The first and third charges both require proof of an assault, but they differ in that the first requires use of a deadly weapon, while the third requires that the victim be a police officer. The first and second both require proof of possession of a gun, but for the first an assault must be shown, while for the second only the defendant's status as an ex-felon need be demonstrated.

70. See p. 973 supra (Sixth Amendment bars use of conviction for collateral estoppel). 
the cold record can reconstruct what the jury rationally must have determined. ${ }^{71}$ Imputing to a jury the logical consequences of its ultimate findings ignores the jury's strongest selling point-injection of community sentiment and a feeling of justice. ${ }^{72}$

\section{A Proposed Solution}

Collateral estoppel, as currently applied, fails to remedy the shortcomings in double jeopardy protection left by the same-offense tests. The problem lies in the restrictive and illogical fashion in which it is applied, as the hypothetical above highlights. A liberalization of collateral estoppel application consonant with the purposes of the double jeopardy clause is accordingly required.

\section{A. Proposal}

To implement the purposes of double jeopardy left unfulfilled by both the same-offense tests and criminal collateral estoppel, the following proposal is offered.

Because any conviction(s) is hereby deemed to punish fully the defendant for all elements alleged against him, and an acquittal of all charges is hereby deemed to establish the falsity of all averments against the defendant alleged by the prosecution and denied by the defendant:

(1) The prosecution shall not allege in its case-in-chief ${ }^{73}$ a fact $^{74}$ previously alleged, and, if he was previously acquitted, denied by the defendant-unless the original and subsequent courts derive their authority from separate

71. See p. 972 supra.

72. Witherspoon v. Illinois, 391 U.S. 510, 519 n.15 (1968); United States v. Dougherty, 473 F.2d 1113, $1130-33$ (D.C. Cir. 1972); see p. 974 supra; Note, Trial by Jury in Criminal Cases, 69 Colum. L. Rev. 419, $432-43$ (1969). Expecting rationality from a jury drawn for its quintessentially arational qualities is irrational. The proposal made by this Note avoids claims of divining jury mentality; it relies instead on the premise that juries render just verdicts, without attempting to explain how such verdicts are reached in individual cases.

73. The government's "case-in-chief" refers to those facts alleged by the government to establish the elements necessary to sustain its prima facie case for conviction. See, e.g., Harris v. New York, 401 U.S. 222 (1971). It does not include impeachment evidence or rebuttal of an affirmative defense. The reason that the proposal excludes impeachment evidence is that, were it included, the defendant could lie about matters that were discussed in previous trials, and the government would be powerless to expose him. Likewise, the proposal applies only to issues raised by the government; otherwise, defendants could immunize certain facts from future scrutiny by raising them by way of affirmative defense in the present trial.

74. Whether the fact sought to be reintroduced is characterized as "ultimate" (a fact necessary for conviction) or "evidentiary" (probative of an ultimate fact) is irrelevant. Wingate v. Wainwright, 464 F.2d 209, 213 (5th Cir. 1972). 
sovereigns
charges $^{76}$

(2) The foregoing shall not apply to:

(a) charges arising from circumstances that occur after commencement of $\operatorname{trial}^{77}$ or from information that comes to the prosecutor's attention after commencement of trial, ${ }^{78}$ provided the prosecutor exercised due diligence prior to trial; ${ }^{79}$

(b) counts the defendant moves to sever and reserve for subsequent adjudication or charges that both sides agree to reserve; 80

75. See note 6 supra (both state and federal governments may prosecute identical offense).

76. The estoppel created by the proposal perpetuates the limitations inherent under existing law in the following respects. First, it does not extend to charges with the same factual base that must be tried by different jurisdictions. See Dunham v. United States, 125 F.2d 895 (5th Cir. 1942). Second, it is inapplicable to charges that must be tried before different courts within the same jurisdiction. See, e.g., State v. Sleeper, 36 Or. App. 227, 584 P.2d 333 (1978) (municipal court conviction of driving under influence of intoxicants does not bar prosecution in circuit court for criminal activity in drugs when both arose from same transaction but neither court had jurisdiction over both); State v. Van Landuyt, 157 N.J. Super. 469, 475-76, 385 A.2d 236, 239 (1978) (superior court prosecution for larceny of auto permissible following municipal court conviction of operating auto without owner's permission).

77. Under this provision, the prosecution will retain the option, enjoyed under current law, of retrying a defendant for perjury committed at his first trial. See, e.g., United States v. Fayer, 573 F.2d 741, 745 (2d Cir.), cert. denied, 439 U.S. 831 (1978) (acquittal of lawyer on charge of wrongfully endeavoring to influence witness does not bar prosecution for perjury in misrepresenting whom he was trying to influence); United States $v$. Gremillion, 464 F.2d 901, 906 (5th Cir.), cert. denied, 409 U.S. 1085 (1972) (acquittal for fraudulent sale of securities followed by prosecution for perjury in denying guilt to grand jury). But see United States v. Nash, 447 F.2d 1382 (4th Cir. 1971) (collateral estoppel bars prosecution for perjury followirg acquittal for mail theft). Double jeopardy objections to this practice have been raised, because it effectively allows the prosecution to retry an acquitted defendant for the underlying substantive offense. E.g., Jay v. State, 15 Ala. App. 255, 73 So. 137 (1916); Note, Perjury by Defendants: The Uses of Double Jeopardy and Collateral Estoppel, 74 HaRv. L. Rev. 752 (1961).

78. See Commonwcalth v. Washington, 481 Pa. 474, 393 A.2d 3 (1978) (after conviction of assault, second prosecution for subsequent death of victim allowed under same-transaction test). If new evidence arises during trial, the prosecutor should be required to inform the court and, upon the defendant's motion, to join the new charges.

79. As presently applied, the double jeopardy clause forbids successive prosecution and cumulative punishment for a greater and lesser included offense. See note 23 supra. Current law excepts, however, those cases in which the state cannot proceed on the greater offense because additional facts necessary to sustain it have not yet occurred or have not been discovered despite exercise of due diligence. Jeffers v. United States, 432 U.S. 137, 151.52 (1977) (plurality opinion).

When the defendant is convicted under this exception on evidence for which he has already been punished, the court exacting the second sentence should credit against it time already served. See United States v. Markus, 603 F.2d 409 (2d Cir. 1979) (time served must be credited upon reconviction of same offense).

80. See Jeffers v. United States, 432 U.S. 137, 152 (1977) (plurality opinion) (defendant who elects to have two offenses tried separately cannot complain of double jeopardy violation). 
(c) charges the prosecutor moves to reserve for subsequent adjudication because they are so complicated that consolidation would overwhelm the jury. ${ }^{81}$

This proposal bars introduction of the same evidence ${ }^{82}$ against the accused $^{83}$ in successive criminal trials ${ }^{84}$ regardless of whether the first trial ended in acquittal or conviction. ${ }^{85}$ The proposal makes no reform for simultaneous prosecutions because if numerous charges are tried together, the Blockburger test already adequately determines whether conviction on more than one charge is permissible. For subsequent prosecutions, the proposal introduces changes. If convicted, the defendant would be deemed to have already been punished adequately for the fact(s) alleged. If acquitted, the alleged fact(s) would be considered false. The prosecutor would therefore have an incentive to include all charges with overlapping evidence in his initial indictment or information, or to move pursuant to (2)(c) to reserve an overlapping charge.

As a corollary effect, the proposal will prevent the government from introducing evidence of similar acts previously alleged against the defendant. ${ }^{86}$ If acquitted in the prior case, the defendant may already

81. See G. Williams, Criminad LAw 684 (2d ed. 1961) ("The jury system is unworkable unless the prosecution is confined to a relatively simple issue which can be disposed of in a relatively short time.")

82. The proposal bars testimony by different witnesses about the same fact; otherwise, the government could easily circumvent its requirements.

83. Under current law as well, criminal collateral estoppel does not apply for the protection of codefendants. E.g., Coleman v. United States, 295 F.2d 555 (D.C. Cir. 1961); State v. Bradley, 361 Mo. 267, 273, 234 S.W.2d 556, 558-59 (1950).

84. The proposal extends neither criminal collateral estoppel to the civil realm, see Helvering v. Mitchell, 303 U.S. 391 (1938) (in subsequent civil suit, no collateral estoppel arises from prior acquittal), nor civil collateral estoppel to the criminal realm, see United States v. Lasky, 600 F.2d 765 (9th Cir. 1979) (dismissal of civil proceedings for mail fraud does not bar criminal prosecution).

85. The proposal applies only after trial and judgment of acquittal or conviction and thus excludes from its ambit the guilty plea, pretrial dismissal, and mistrial. Under cur. rent law, collateral estoppel cannot arise before final verdict. See FTC v. Food Town Stores, Inc., 547 F.2d 247, 249 (4th Cir. 1977) (per curiam) (order granting stay not final adjudication on merits, hence no estoppel); United States v. Ten Firearms \& TwentyFour Rounds, 444 F. Supp. 305, 308 (N.D. Tex. 1977) (no collateral estoppel for failure to return an indictment); People v. Prewitt, 52 Cal. 2d 330, 340, 341 P.2d 1, 6 (1959) (no collateral estoppel following release after preliminary hearing). Because after mistrial the defendant has not been punished on the basis of the evidence introduced nor has the jury determined facts in his favor, the proposal does not come into play. Differences between the trial and guilty-plea contexts also justify the distinction that the proposal draws between them. It is speculative upon which evidence the prosecution would have relied at trial when the defendant pleads guilty. Moreover, the defendant can often protect himself against future charges for specific offenses by plea-bargaining.

86. Similar-acts evidence, see note 30 supra, will still be admissible under the proposal in criminal cases when it concerns previous acts for which the defendant has not been 
have proven the untruthfulness of this evidence. ${ }^{87}$ And if convicted, the jury ${ }^{88}$ should not be induced to convict ${ }^{89}$ on the basis of elements from the defendant's past for which he has already been punished. ${ }^{90}$

\section{B. Merits of the Proposal}

Unlike other suggestions for improving double jeopardy protection, ${ }^{91}$ the instant proposal does not break radically from existing law and thus can be instituted with a minimum of discontinuity..$^{92}$ By ex-

tried. See Lisenba v. California, 314 U.S. 219, $227-28$ (1941) (evidence of drowning of defendant's former wife, for which no criminal charges filed, admitted in trial for drowning of later wife); United States v. Juarez, 561 F.2d 65, 70 (7th Cir. 1977) (similar acts evidence introduced when charges of prior crime had been dismissed).

87. The jury in the prior trial may well have found the point in the defendant's favor, yet the jury in the second case may be tempted to convict on the basis of the previous crime. See Bray, supra note 15 , at 514 .

88. At sentencing, once the jury's role is completed, the state may point out previous convictions to the judge. The fact of the defendant's prior convictions is thereby admitted, not to induce a fact-finder to find guilt based on evidence already introduced, but for the legitimate purpose of illuminating the defendant's character for rehabilitative and punitive purposes. See United States ex rel. McCray v. Rundle, 422 F.2d 354, 356 (3d Cir. 1970) (evidence of prior conviction admitted for sentencing purposes only).

89. The exclusion of similar-acts evidence does not extend to its use for impeachment purposes, for were it excluded, the defendant could commit perjury concerning prior crimes without fear of being exposed. See Bray, supra note 15, at 495-97; cf. Harris v. New York, 401 U.S. 222 (1971) (evidence tainted by Miranda violation excluded from prosecution's case-in-chief but allowed for impeachment).

90. The government frequently seeks to introduce such evidence under the guise of proving one element of its case-in-chief when the underlying purpose is the illegitimate one of discrediting the defendant's character. E.g., United States v. Carter, 482 F.2d 738, 740 (D.C. Cir. 1973); see, e.g., United States v. Burkhart, 458 F.2d 201 (10th Cir. 1972). Beyond its enormous consumption of court time, United States v. Mastrototaro, 455 F.2d 802 (4th Cir.), cert. denied, 406 U.S. 967 (1972), such a practice violates the double jeopardy clause, cf. Bruton v. United States, 391 U.S. 123 (1968) (impossible for jury to segregate introduction of evidence to only one purpose).

91. Proposals have included the following: (1) Combine the same-transaction test with the right of the state to appeal. See Mayers \& Yarbrough, Bis Vexari: New Trials and Successive Prosecutions, 74 Harv. L. REv. 1, 35 (1960). This proposal was rejected in United States v. Wilson, 420 U.S. 332,352 (1975). (2) Undertake a general codification of existing criminal laws into same-offense categories. See J. Sigler, supra note 1, at 195. This would obviously require comprehensive legislative action. (3) Change the sameevidence test from "any" different evidence to "materially" different evidence. See Haddad \& Mulock, supra note 11, at 533. Absent promulgation of objective criteria of what is "material," this proposal would relegate defendants to judges' subjectivity, a fault discussed in note 40 supra. (4) Combine all civil and criminal claims arising from the same transaction. See Note, supra note 24, at 354 \& n.80; Note, Professor George $H$. Dession's Final Draft of the Code of Correction for Puerto Rico, 71 YALE L.J. 1050, 1115 (1962). Present law separates the civil and criminal spheres. Cf. United States v. United Mine Workers, 330 U.S. 258, 364 (1947) (Rutledge, J., dissenting) ("our Constitution has totally rejected, the continental system of compounding criminal proceedings with civil adjudications"). Further, the same-transaction test remains unworkably vague. See p. 968 supra. (5) Eliminate the double jeopardy clause. See Comley, Former Jeopardy, 35 YalE L.J. 674, 688 (1926). The Fifth Amendment currently stands in the way of that proposal.

92. The proposal could be adopted by either the federal courts as an extension of current law or by the state courts as an interpretation of local double jeopardy law. See, 
tending principles of criminal collateral estoppel to supplement the Blockburger test, it introduces a workable same-transaction test. The proposal uses an intuitive notion of the same transaction to eliminate the possibility of definitional manipulation that fatally flaws the existing same-transaction test. Crimes related as parts of the same transaction cannot be tried without overlapping evidentiary presentation. Thus, the proposal would require all such crimes to be tried simultaneously. To the extent temporally proximate crimes can be prosecuted separately under the proposal, they must be supported by totally different evidence and thus cannot be incidents of the same transaction, as properly defined. The same-transaction test was formulated both to prevent repetition of the same evidence at succeeding trials and to protect the defendant from twice being placed in jeopardy on the same totality of circumstances. This proposal avoids both harms.

The double jeopardy policy against repeated trial for the same offense applies equally to a second trial on the same evidence. This proposal will free defendants from having to face retrial for the same statutorily-defined offense or to relitigate the same facts under the guise of different statutory provisions or multiple violations of the same provision. ${ }^{93}$ Therefore, the second two prosecutions described in the hypothetical above would be foreclosed. The proposal would permit the defendant to be tried for all three crimes, but only as multiple counts at one trial. Society is thus afforded ample opportunity to seek redress for all violations of its statutes, while the defendant is protected against successive prosecutions on the same evidence. ${ }^{34}$ The proposal,

e.g., Commonwealth v. Campana, 455 Pa. 622, 314 A.2d 854, cert. denied, 417 U.S. 969 (1974) (same-transaction test adopted pursuant to supervisory powers); State v. Brown, 262 Or. 442, 453, 497 P.2d 1191, 1196 (1972), overruled in part, State v. Hammang, 271 Or. 749,756 n.4, 534 P.2d 501, 504 n.4 (1975) (same-transaction test adopted under Oregon Constitution). Because the proposal does not require the reversal of any constitutional precedents, it could be adopted through legislation.

93. An example of the latter tactic is Ciucci v. Illinois, 356 U.S. 571 (1958), in which the defendant had murdered his wife and three children. The defendant was convicted seriatim of the murder of his wife, the murder of one child, and the murder of another. At each of the three trials, evidence of all four murders was tendered. The prosecution "in effect tried the accused for four murders threc consecutive times, massing in each trial the horrible details of each of the four deaths." Id. at 575 (Douglas, J., dissenting). The claim that each jury considered only evidence relevant to the specific charge before them is disingenuous, for evidence of the additional murders was unnecessary to prove the charged murder in each trial; rather, it was introduced for the illicit purpose of prejudicing the jury against the defendant. Nonetheless, the Supreme Court upheld his convictions under the same-evidence test.

94. Under the present proposal, as soon as the government seeks to introduce any previously introduced evidence, the defendant can have it excluded. The same-evidence test, by contrast, allows vexatious litigation. It forces the defendant to endure prosecution, waiting for the government to rest its case before he can brief and argue substantial 
by protecting the defendant from needless litigation, from allegation of facts a jury may already have determined in his favor, and from double punishment upon proof of the same facts, thus fulfills the goal that "the Double Jeopardy Clause [be] liberally construed in light of its great historic purpose to protect the citizen from more than one trial for the same act." 95

identity of evidence. The defendant is thus forced to suffer through jeopardy in order to prove it was barred $a b$ initio. Thus, the instant proposal better fulfills the goals of the double jcopardy clause. Cf. Gully v. Kunzman, 592 F.2d 283, 287 (6th Cir.), cert. denied, 442 U.S. 924 (1979) (double jeopardy means constitutional immunity from having to undergo hazard of second trial).

95. Gore v. United States, 357 U.S. 386, 396 (1958) (Douglas, J., dissenting). 